\title{
Procalcitonin-guided antibiotic treatment of respiratory tract infections in a primary care setting: are we there yet?
}

\author{
*Rune Aabenhus ${ }^{\mathrm{a}}$, Jens-Ulrik Stæhr Jensen ${ }^{\mathrm{b}, \mathrm{c}}$ \\ a Research Unit for General Practice, University of Copenhagen, Denmark \\ b ICU Division, Copenhagen HIV programme (CHIP), University of Copenhagen, Denmark \\ Department of Clinical Microbiology, Copenhagen University Hospital, Hvidovre, Denmark
}

Received 15th February 2011; revised 11th April 2011; accepted 25th April 2011; online 2nd August 2011

\begin{abstract}
Clinical signs of infection do not allow for correct identification of bacterial and viral aetiology in acute respiratory infections. A valid tool to assist the clinician in identifying patients who will benefit from antibiotic therapy, as well as patients with a potentially serious infection, could greatly improve patient care and limit excessive antibiotic prescriptions. Procalcitonin is a new marker of suspected bacterial infection that has shown promise in guiding antibiotic therapy in acute respiratory tract infections in hospitals without compromising patient safety. Procalcitonin concentrations in primary care are low and can be used primarily to rule out serious infection. However, procalcitonin measurement should not be used as the sole basis for clinical decisions; clinical skills are prerequisites for the correct use of this new tool in practice. At present there is no point-of-care test for procalcitonin with acceptable precision, severely hampering its application in primary care. This article reviews the physiology of procalcitonin, describes the assays available for its measurement, evaluates the present evidence from primary care on its use to identify correctly patients who are likely to benefit from antibiotic treatment and to rule out serious infections, and comments on further research to determine a future role for procalcitonin in primary care.

(C) 2011 Primary Care Respiratory Society UK. All rights reserved.

R Aabenhus and JS Jensen. Prim Care Respir J 2011; 20(4): 360-367

http://dx.doi.org/10.4104/pcrj.2011.00064
\end{abstract}

Keywords biomarkers, acute respiratory infections, procalcitonin, primary care, diagnostic tests

\section{Introduction}

An urgent issue in modern healthcare services is the increasing level of antibiotic resistance in common pathogenic microorganisms. At present the development of antimicrobial drugs is at a historically low level, ${ }^{1}$ so controlling the development of resistance by limiting excessive and inappropriate use of antibiotics is pivotal to the future treatment of bacterial infections in primary care as well as in hospitals. Any reduction in antibiotic consumption will have a relatively higher impact when done in a primary care setting where most antibiotic prescriptions are issued. ${ }^{2,3}$

The decision on when to prescribe antibiotics for a respiratory tract infection (RTI) in primary care is challenging and is often based solely on clinical symptoms, which is known to be of low sensitivity and specificity ${ }^{4,5}$ and with a high degree of inter-observer variability. ${ }^{6}$ Prescription practices for similar illnesses vary substantially between European countries, highlighting the need for evidence-based guidelines incorporating strategies to help reduce inappropriate antibiotic treatment.

Several attempts have been made to decrease the use of antibiotics in primary care; however, a Cochrane review ${ }^{8}$ found only a limited effect, with a multifaceted approach at most offering a decrease in antibiotic prescriptions of $10-15 \%$. Guidelines for prudent antibiotic prescription are frequently issued but adherence to these in daily clinical practice is far from optimal. ${ }^{9}$

At present, methods for differentiating bacterial from viral causes of RTI - including clinical symptom scores and radiological investigations - have not proved to be valid. 5,6,10 However, the potential for controlling antibiotic resistance and improving patient care by better diagnosis is obvious as

\footnotetext{
*Corresponding author: Dr Rune Aabenhus, Research Unit for General Practice, Copenhagen University, Øster Farimagsgade 5, box 2099, 1014 Copenhagen, Denmark. Tel: +453532 7171 Fax: +45 35327131 E-mail: runeaa@sund.ku.dk
} 
$50-75 \%$ of RTIs in primary care are of viral origin. ${ }^{2,11}$ Interest has recently been centred on biomarkers to determine the aetiology of RTIs and hence the need for antibiotic treatment. Biomarkers of infection

As a consequence of the inherent uncertainty in clinical judgements, doctors try to optimise their performance by using diagnostic tools. Biomarkers such as white blood cell count, Creactive protein (CRP), and procalcitonin have been introduced to assist the clinician in diagnosing and monitoring infection. They act as surrogate measures, mirroring the extent and severity of an infection. An ideal biomarker for use in infection should enable rapid determination of the cause of fever by accurately predicting the presence or absence of bacterial infection, thereby allowing for appropriate therapeutic responses without adding excessive work for the clinician or costs to society. A biomarker suitable for use in primary care must be a point-of-care test which effectively discriminates milder infections from serious infections that would benefit from antibiotic treatment, in order to minimise excessive antibiotic prescriptions and limit concomitant side-effects. ${ }^{12} \mathrm{~A}$ feasible and valid test would be warranted by many GPs to increase the possibility of 'selling' decisions not to prescribe antibiotics to patients. ${ }^{13}$ However, as with other surrogate tests, no ideal biomarker exists because they are subject to measurement errors, inappropriate handling by investigators, and differences in physiological responses to various kinds of infectious agents. ${ }^{14}$

This review will focus on the use of procalcitonin in primary care as it has been demonstrated to be clinically useful in a range of different patient populations and has proved to be valid in assisting the clinician in identifying patients who do not need antibiotic treatment. ${ }^{15-17}$

\section{Physiology of procalcitonin}

Procalcitonin is a prohormone of the calcium homeostasis hormone calcitonin. ${ }^{18}$ In non-infectious conditions it is produced in the neuroendocrine medullary C-cells of the thyroid gland. In normal subjects circulating procalcitonin concentrations are low $(<0.05 \mathrm{ng} / \mathrm{mL}){ }^{19}$ but bacterial infections selectively induce an increase in the concentration of procalcitonin because both endotoxins (lipopolysaccharides) from the bacterial cell wall and host responses to infection activate the production of procalcitonin, mainly in parenchymal tissues. This results in an accumulation of procalcitonin because, unlike neuroendocrine cells, parenchymal cells lack the ability to cleave procalcitonin into its mature form, calcitonin. ${ }^{20}$ Of note, interferon-gamma from predominantly viral infections blocks the procalcitonin response in human cells. ${ }^{21}$ The increase in the procalcitonin concentration following stimulation is very large (up to $>10,000$ times) ${ }^{22}$ and fast. It can be detected in serum 2-6 hrs after stimulation of healthy individuals with endotoxins from E. coli, maintaining a high level plateau for the next $24 \mathrm{hrs},{ }^{23}$ and can be detected for up to 7 days. ${ }^{18}$ The half-life is approximately $24 \mathrm{hrs}$, which is partly dependent on renal function. ${ }^{24}$ Patients with verified bacterial infections have higher procalcitonin concentrations than those with nonbacterial (including viral) infections. ${ }^{25,26}$ This is also true for respiratory pathogens such as Streptococcus pneumoniae and Haemophilus influenzae which produce high procalcitonin concentrations in infection, ${ }^{27,28}$ whereas the influenza virus exhibits lower procalcitonin concentrations. ${ }^{29}$

The exact role of procalcitonin in inflammation and the host response is not yet fully understood and is the subject of rigorous research. In severe infections, serial measurements of procalcitonin in patients with sepsis can predict mortality ${ }^{30}$ and administration of procalcitoin to hamsters with sepsis increased mortality. ${ }^{3}$

The high sensitivity and corresponding high negative predictive value for serious and presumed bacterial infection may allow the identification of patients who would benefit from antibiotic treatment of RTIs in primary care settings. ${ }^{14,32,33}$

\section{Procalcitonin assays currently available Point-of-care tests}

The Brahms PCT-Q ${ }^{\circledR}$ (Brahms Diagnostica, Hennigsdorf, Germany), a manual assay that applies a chromatographic semiquantitative technique (cut-off $<0.5 \mathrm{ng} / \mathrm{mL}, 0.5-2.0 \mathrm{ng} / \mathrm{mL}$, $2.0-10 \mathrm{ng} / \mathrm{ml},>10 \mathrm{ng} / \mathrm{mL}$ ) providing results in $30 \mathrm{~min}$, is the only existing point-of-care test. However, this assay performs poorly, ${ }^{34}$ and semi-quantitative measurements limit the possibilities of interpreting a trend with consecutive measurements.

\section{Laboratory-based tests}

Quantitative procalcitonin assays are currently available only as laboratory tests. The Brahms PCT LIA ${ }^{\oplus}$ test (former LUMI) (Brahms Diagnostica) is an immunoluminometric assay which was used extensively until about 2003 but is still available.

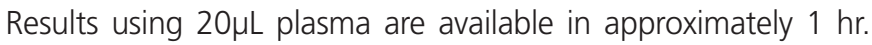
However, the target interval for localised infections $(0.1-1.0 \mathrm{ng} / \mathrm{mL})^{35}$ and the interassay variation of $9-82 \%$ in this range $\mathrm{e}^{30}$ limits its use in a primary care setting. The Brahms PCT KRYPTOR $^{\oplus}$ test (Brahms Diagnostica) is a rapid and more sensitive laboratory-based assay, providing results in $20 \mathrm{~min}$. The fully automated assay uses time-resolved amplified cryptate emission and has a functional sensitivity of $0.06 \mathrm{ng} / \mathrm{mL}$. Interassay variation is $<8 \% .{ }^{36}$ Procalcitonin analysis has recently become available on other broadly used routine laboratory systems including VIDAS ${ }^{\oplus}$ (BioMérieux, Paris, France) and Elecsys ${ }^{\circledast}$ (Roche Diagnostics, Basel, Switzerland).

\section{Cut-off ranges for procalcitonin-guided antibiotic therapy of RTls}

Suggested cut-off ranges for procalcitonin-guided antibiotic 
Figure 1. Procalcitonin-based algorithms. Suggested cutoff levels for procalcitonin-guided antibiotic treatment of acute respiratory tract infections. Both algorithms have been used in primary care but were originally developed in emergency clinics. Burkhardt et al. ${ }^{38}$ simplified the algorithm to be more feasible in primary care

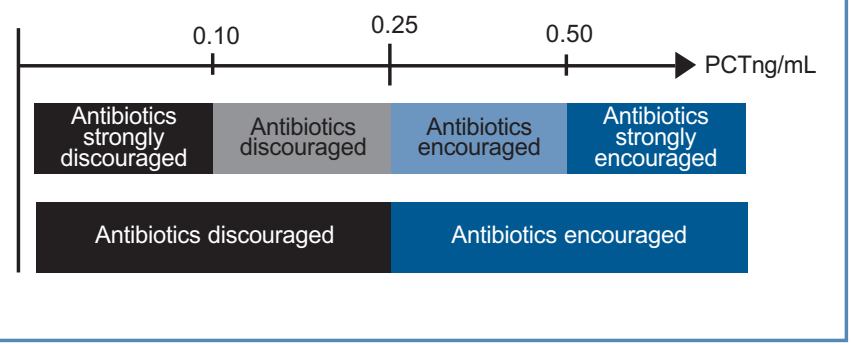

strategies have been tested mainly in studies of lower RTIs in hospital emergency settings, and in two studies from primary care. $^{37}$ The application of these procalcitonin cut-off values in trials with $>3,500$ patients has not shown any changes in patient outcome or rate of complications when compared with the usual antibiotic guidelines, i.e. 'standard of care'. ${ }^{37}$ In short, the standard cut-off ranges used in these trials (non-ICU settings) have resulted in the following recommendations: antibiotics are (i) strongly discouraged at procalcitonin concentrations $<0.1 \mathrm{ng} / \mathrm{mL}$; (ii) discouraged with procalcitonin concentrations of $0.11-0.24 \mathrm{ng} / \mathrm{mL}$; (iii) encouraged when procalcitonin concentrations were $0.25-0.5 \mathrm{ng} / \mathrm{mL}$; and (iv) strongly encouraged with procalcitonin concentrations $>0.5 \mathrm{ng} / \mathrm{mL}$. Recently, the following simple version has been suggested for primary care: antibiotics are discouraged at procalcitonin concentrations $<0.24 \mathrm{ng} / \mathrm{mL}$ and encouraged at procalcitonin concentrations $\geq 0.25 \mathrm{ng} / \mathrm{mL}$ (Figure 1). ${ }^{38}$

\section{Assessment of new diagnostic markers against a 'gold standard' in RTls}

Traditionally, new diagnostic tools are tested against a 'gold standard' for identifying the specified condition. Despite the logic of this approach, the strategy is problematic as many clinical conditions do not have an acceptable 'gold standard', making assessment of new biomarkers difficult. In many cases the main motivation for introducing a new diagnostic tool is dissatisfaction with the alleged 'gold standard'. This is the situation in the field of inflammatory markers and bacterial infection. Diagnosis of bacterial RTI is often not sufficiently reproducible when done on clinical judgement alone. ${ }^{4,6}$ The 'gold standard' for bacterial pneumonia is often based on radiographic evaluations. ${ }^{39}$ It is important to acknowledge the lack of accuracy of this 'gold standard' as since a bacterial aetiology is established in fewer than $30 \%$ of radiographic infiltrates from patients with community-acquired pneumonia (CAP), a viral cause is suspected in a minimum of $30 \%$ of radiographic infiltrates, and the diagnosis of a pneumonic infiltrate is challenging, even for experienced radiologists. ${ }^{40,41}$ Microbiological evaluations are likewise controversial for a definite diagnosis as many patients are colonised with common respiratory pathogens. This is especially the case in chronic obstructive pulmonary disease (COPD). ${ }^{42}$

Of note, a perfect biomarker (100\% sensitivity and 100\% specificity) for bacterial infection tested against the present diagnostic criteria in a primary care setting will probably perform far from perfectly as the 'gold standard' is not an entirely true picture of the pathophysiological processes taking place.

Apart from the issue of a true 'gold standard', the clinical setting is important since the performance of any test is affected by the disease prevalence in the target population. The positive predictive value is 'a priori' lower in patients with a low probability of bacterial infection, e.g. in primary care as opposed to hospital settings.

A different approach from the above-mentioned ${ }^{32}$ - for example, the need for antibiotic treatment - is a patientorientated concept. This concept bypasses the need for an alleged 'gold standard' and focuses on patient recovery and other measurable benefits or harms to the patient. Randomised controlled trials (RCTs) that measure the medical outcome of standard versus procalcitonin-guided antibiotic therapy may better estimate the utility of biomarkers in patients with RTIs. If the patient recovers without antibiotics at the same speed and with comparable rates of complications (hospitalisation, mortality, and number of re-infections), it may be concluded that the infection was of non-bacterial origin or so mild that the immune defence could clear the infection unassisted..$^{43}$

Box 1. Studies on use of procalcitonin in primary care: search strategy

Electronic searches were performed in PUBMED, EmBase, and Cochrane CENTRAL (latest January 2011). No limitations of age or study type were applied. Language limitations were not applied, but all relevant papers were in English. Combinations of the phrases 'procalcitonin', 'respiratory tract infections', 'community acquired pneumonia', 'general practice', and 'primary care' were used. Supplementary searches included reviewing reference lists of all available papers and review articles. Finally, we made personal contact with colleagues and collaborators working in the field to identify potentially relevant studies.

\section{Study selection}

Population: participants had to (i) present with symptoms clinically determined to be RTIs and (ii) be enrolled in a primary care setting

Study aim: to assess the value of procalcitonin use, e.g. to determine the need of antibiotic treatment in RTIs using a reference (gold) standard or measures of patient recovery. 


\begin{tabular}{|c|c|c|c|c|c|c|c|c|c|}
\hline Type of study & Year & Author & $\begin{array}{l}\text { Participants } \\
\text { (n) }\end{array}$ & Illness & Follow up & Assay & $\begin{array}{l}\text { Main } \\
\text { outcome }\end{array}$ & $\begin{array}{l}\text { Secondary } \\
\text { outcomes }\end{array}$ & Remarks \\
\hline Observational & 2003 & Korppi et al..$^{44}$ & $\begin{array}{l}\text { Children } \\
\text { (190) }\end{array}$ & CAP & - & PCT LIA & $\begin{array}{l}\text { PCT lacked ability to } \\
\text { predict the etiology } \\
\text { of infiltrates on } \\
\text { chest x-ray }\end{array}$ & $\begin{array}{l}\text { PCT did not } \\
\text { predict etiologies } \\
\text { (serological } \\
\text { testing) }\end{array}$ & $\begin{array}{l}\text { PCT LIA } \\
\text { insensitive. } \\
\text { Problem of } \\
\text { gold standard }\end{array}$ \\
\hline Observational & 2007 & Holm et al..$^{28}$ & $\begin{array}{l}\text { Adults } \\
\text { (364) }\end{array}$ & CAP & - & Kryptor & $\begin{array}{l}\text { PCT lacked ability to } \\
\text { predict the etiology } \\
\text { of infiltrates on } \\
\text { chest x-ray }\end{array}$ & $\begin{array}{l}\text { PCT did not } \\
\text { predict etiology } \\
\text { or adverse } \\
\text { outcome }\end{array}$ & $\begin{array}{l}\text { Problem of } \\
\text { gold standard }\end{array}$ \\
\hline Observational & 2010 & Burkhardt et al. ${ }^{38}$ & Adults (702) & RTI & - & Kryptor & $\begin{array}{l}\text { Characterisation of } \\
\text { PCT levels in RTI }\end{array}$ & - & $\begin{array}{l}\text { PCT values } \\
\text { generally low }\end{array}$ \\
\hline RCT & 2008 & Briel et al. ${ }^{16}$ & Adults (458) & RTI & $14 / 28$ & Kryptor & $\begin{array}{l}\text { No difference in days } \\
\text { with restricted } \\
\text { activities (8.7 vs 8.6) }\end{array}$ & $\begin{array}{l}72 \% \text { decrease } \\
\text { in ABx. No } \\
\text { differences in } \\
\text { adverse outcomes }\end{array}$ & $\begin{array}{l}\text { Many diagnoses } \\
\text { included that a } \\
\text { priori did not } \\
\text { need } \mathrm{ABx}\end{array}$ \\
\hline RCT & 2010 & Burkhardt et al. ${ }^{38}$ & Adults (550) & RTI & $14 / 28$ & Kryptor & $\begin{array}{l}\text { No difference in days } \\
\text { with restricted } \\
\text { activities } \\
\text { (9.00 vs } 9.04 \text { ) }\end{array}$ & $\begin{array}{l}42 \% \text { decrease } \\
\text { in ABx. No } \\
\text { differences in } \\
\text { adverse outcome. }\end{array}$ & $\begin{array}{l}\text { Simplified } \\
\text { PCT algorithm. }\end{array}$ \\
\hline
\end{tabular}

$\mathrm{PCT}=$ procalcitonin; $\mathrm{CAP}=$ community-acquired pneumonia; $\mathrm{RCT}=$ randomized controlled crial; $\mathrm{RTI}=$ respiratory tract infections (acute); $\mathrm{ABx}=$ antibiotic treatments

\section{Procalcitonin in primary care: observational studies}

Procalcitonin concentrations in suspected upper and lower RTIs including verified bacterial pneumonia have been assessed in three observational studies in primary care (see Box 1 and Table 1).

Korppi et al. ${ }^{44}$ investigated the usefulness of procalcitonin to differentiate between viral and bacterial causes of radiologically-confirmed CAP in 190 Finnish children in a primary care setting. Procalcitonin was measured by the Brahms PCT LIA test ${ }^{\circledR}$ (today considered inappropriate - see above). Sixty percent of the procalcitonin measurements were below the functional assay sensitivity of $0.5 \mathrm{ng} / \mathrm{mL}$. No differences in procalcitonin concentrations were observed between patients admitted to hospital and those treated as outpatients, nor did procalcitonin indicate viral or bacterial aetiology.

Holm et al..$^{28}$ evaluated 364 Danish adults diagnosed with a lower RTI by their GP. Procalcitonin concentrations, measured with the Brahms PCT KRYPTOR ${ }^{\circledast}$ assay, were correlated with chest $\mathrm{x}$-rays and microbial aetiology. Of the suspected cases of lower RTI, 13\% had radiographically-verified CAP. In the group of patients with suspected pneumonia by the 'gold standard', $30 \%$ had normal procalcitonin concentrations $(<0.06 \mathrm{ng} / \mathrm{mL})$. Of the patients without pneumonia only $1 \%$ had procalcitonin concentrations $>0.25 \mathrm{ng} / \mathrm{mL}$, and all eight patients with procalcitonin concentrations $>0.5 \mathrm{ng} / \mathrm{mL}$ had radiographicallyverified CAP, four of whom were subsequently identified with S. pneumoniae bacteraemia.

Burkhardt et al. ${ }^{38}$ characterised procalcitonin concentrations using the Brahms PCT KRYPTOR ${ }^{\circledR}$ assay in 702 adults with RTIs in primary care. Clinical diagnoses were predominantly lower RTIs, mainly acute bronchitis. The results confirmed that procalcitonin concentrations in patients with suspected RTI in primary care settings are low, with around 95\% being $<0.1 \mathrm{ng} / \mathrm{mL}$, which is considered to indicate a minimal risk of a bacterial aetiology with no benefit of antibiotic treatment (Figure 2).

\section{Procalcitonin-guided antibiotic therapy in primary care: randomised trials}

A procalcitonin-guided antibiotic strategy may have the potential to help in reducing antibiotic use in patients with suspected RTI in primary care. Two studies have compared standard care of RTIs with procalcitonin-guided antibiotic therapy in a randomised design, ${ }^{16,38}$ (see Box 1 and Table 1).

A multicentre RCT involving 53 primary care physicians and 458 adult patients with acute RTIs judged to be in need of antibiotic treatment was carried out in Switzerland by Briel et al..$^{16}$ to assess the effect of procalcitonin-guided antibiotic treatment using the Brahms PCT Kryptor ${ }^{\circledast}$ assay. The study physicians were trained in acute RTI and management guidelines were issued to participants. The study was a noninferiority trial with a pre-specified criterion of an increase of $<1$ day in restricted activities in the procalcitonin intervention group. For safety, an additional procalcitonin measurement was obtained after 6-24 hrs in the procalcitonin group if antibiotic treatment was initially withheld. The attending GP was allowed to overrule the procalcitonin algorithm if withholding 
Figure 2 Percentage of patients with procalcitonin concentrations below certain limits in primary care settings. The figure is constructed using median and interquartile ranges in adults. Since only $10-25 \%$ of patients suspected of acute respiratory tract infection (ARI) had procalcitonin concentrations above $0.1 \mathrm{ng} / \mathrm{mL}$, it should be expected that $75-90 \%$ of patients attending their GP with ARI will not be prescribed antibiotics if a cut-off of $0.1 \mathrm{ng} / \mathrm{mL}$ is applied. Procalcitonin should at present be used to stop/withhold antibiotics. At procalcitonin concentrations above the cut-off value, antibiotic treatment should rely on history and clinical examination. Inclusion criteria varied slightly between the three studies used; this may be the reason for the discrete difference in the procalcitonin concentrations in the populations

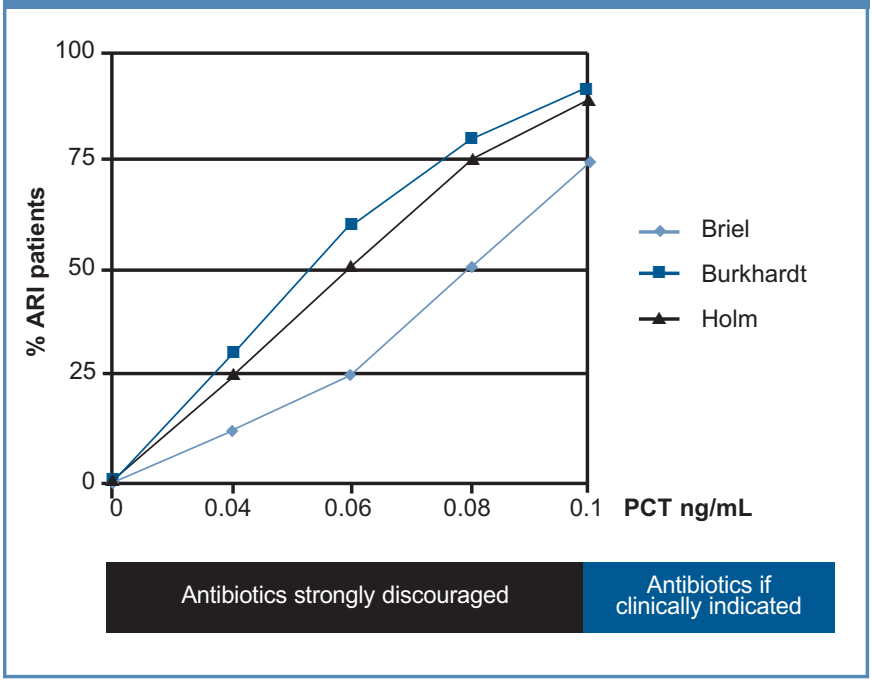

antibiotics was judged to be a safety risk for the patient. Cutoff values for procalcitonin-guided antibiotic treatment are shown in Figure 1. Both upper and lower RTIs were included on the basis of clinical judgement. Some 50\% were lower RTIs, predominantly acute bronchitis. The adjusted increase in restricted activities at 14 days follow-up in the procalcitonin intervention group was 0.14 days $(95 \% \mathrm{Cl}-0.53$ to 0.81$)$ (i.e. $3.6 \mathrm{hrs})$, confirming non-inferiority within the power limits of the trial. Furthermore, a decrease of $72 \%(95 \% \mathrm{Cl} 66 \%$ to $78 \%$ ) in antibiotic prescription rates (25\% vs. 97\%) was demonstrated, with the most pronounced effect in acute bronchitis and upper RTIs. No differences in relapsing infections or complications were detected.

The results of the study by Briel et al. ${ }^{16}$ were confirmed and elaborated by Burkhardt et al. ${ }^{38}$ who simplified the procalcitonin treatment algorithm by limiting the instructions to no antibiotic treatment with procalcitonin concentrations $<0.25 \mathrm{ng} / \mathrm{mL}$ and thus advising antibiotic treatment at procalcitonin concentrations $>0.25 \mathrm{ng} / \mathrm{mL}$ (Figure 2). Burkhardt et al..$^{38}$ also omitted the $24 \mathrm{hr}$ re-evaluation of the procalcitonin concentration, thereby attempting to make the strategy more feasible for use in a primary care setting. However, the option of clinicians to overrule the procalcitonin algorithm was maintained. No previous training of participating physicians in evidence-based medicine was done and patients were consecutively enrolled, thus providing a realistic primary care setting and minimising pre-selection. Patients primarily had upper RTIs (65\%) and only three patients had pneumonia according to the attending physician. The main outcome namely, days with restriction from an RTI at 14 days - was comparable between the groups (9.04 vs. 9.00). This was confirmed when adjusting for potential confounders. The procalcitonin-guided group had a $42 \%$ lower exposure to antibiotic therapy $(p<0.0005)$ and no differences were observed in the number of clinical reassessments performed or complications.

The evidence from the two RCTs of procalcitonin-guided antibiotic treatment of RTIs in primary care thus suggests that procalcitonin is potentially of clinical use in identifying patients who do not need antibiotic treatment, and introduction of this principle may facilitate a substantial reduction in antibiotic exposure.

\section{Limitations of procalcitonin measurements}

Procalcitonin measurement may produce false negative and false positive results. ${ }^{22}$ Not all micro-organisms produce similar increases in procalcitonin concentrations, and even viral causes may present with procalcitonin concentrations above $0.5 \mathrm{ng} / \mathrm{mL} .^{45}$ However, caution should be exercised in the interpretation of established viral infection since secondary bacterial infection may complicate the existing condition (e.g. influenza infection complicated by bacterial pneumonia). Awareness of patients with suspected mycoplasma infection is warranted as procalcitonin levels are generally low with this organism. ${ }^{28}$ However, this is not a general feature of atypical pneumonias. ${ }^{33}$ False negative values may also be of concern in localised states of infection (e.g. abscesses) and even in the early stages of systemic infections. ${ }^{37}$

The cost of procalcitonin measurements is a key point in considering the potential of procalcitonin-guided antibiotic measurements in primary care. To be feasible in modern healthcare systems with tight budgets, the price of a procalcitonin-guided strategy and that of a more traditional approach should be at least comparable. Other issues to consider include ease of use, quality assurance, controls, shelf-life, storage of tests, and time taken to perform the test. However, information regarding these issues is lacking as no rapid point-of-care procalcitonin assay presently exists - which is an essential requirement before a procalcitonin-guided antibiotic treatment strategy for RTIs can be applied in primary care. 


\section{Conclusion and perspectives}

Physicians and patients share a common goal of limiting the duration and intensity of RTIs and preventing complications from infections and drug therapy (i.e. side-effects). Apart from ensuring the best treatment and patient care, the GP plays an important role in preventing the emergence of bacterial resistance to antibiotics. Difficulties in reducing present prescribing practices may in part be due to doctors' fear of missing a potentially treatable RTI, especially a lower RTI.46,47 Clearly, a validated tool to predict benefit from antibiotic prescribing by assisting clinical assessment and differentiating mild from serious infection of presumed bacterial aetiology is highly warranted. To date, biomarkers seem to be powerful tools for reducing antibiotic prescriptions by ruling out serious infection.

The CRP test is more widely used because of the existing point-of-care tests and, at present, it is the best available tool to reduce antibiotic exposure in RTI, even though its potential has not been thoroughly validated. Two recent Dutch RCTs of CRP antibiotic guidance in patients with cough and RTIs found a $40 \%$ reduction in antibiotic prescriptions. ${ }^{48,49}$ However, the studies were not powered to detect a difference in patient recovery.

Procalcitonin-guided antibiotic treatment is a promising and increasingly validated tool for treating RTI in primary care. It has the possibility of reducing unnecessary antibiotic prescriptions (42-72\%) with no differences in health impairment or risk of complications. The performance of procalcitonin and other markers of infection in confirming 'classical' but poorly defined diagnostic entities such as pneumonia or bronchitis is not convincing. However, this may not be of great importance if more interventional RCTs are undertaken to (1) increase the power of the results and confirm the safety of the strategy; (2) estimate better the net effect on antibiotic reduction; (3) investigate strategies that make procalcitonin-guided antibiotic treatment logistically feasible on a broader scale in primary care, e.g. by introducing point-of-care tests; and (4) access and compare the cost of a procalcitonin-guided strategy versus standard care.

Even taking into account the low degree of serious infections found in primary care, ${ }^{50}$ the current evidence suggests that procalcitonin is a step towards tailored antibiotic treatment for patients with a high probability of a bacterial infection likely to benefit from antibiotic therapy, thus minimising unnecessary antibiotics for viral or other selflimiting diseases without compromising patient safety. Procalcitonin concentrations in primary care settings are low (Figure 2), indicating that it may be used as a negative predictor (e.g. to rule out the presence of a serious infection). Some studies suggest that procalcitonin concentrations at hospital admission can predict the severity and outcome of
CAP and specify that low procalcitonin concentrations may independently identify patients at low risk of death within clinical scoring systems (e.g. CRB-65, CURB-65, and Pneumonia Severity Index). ${ }^{51,52}$ A cut-off point of $0.1 \mathrm{ng} / \mathrm{mL}$ for antibiotic therapy would still result in $75-90 \%$ of patients with suspected RTI being excluded from antibiotic therapy (Figure 2) and no risk of increased mortality. At present, no repeat or safety procalcitonin testing is warranted on a routine basis. It is important to acknowledge that a low procalcitonin concentration does not mean 'no treatment' or 'no hospital admission', but indicates a low probability of benefit from antibacterial drugs. Procalcitonin can be used to withhold or stop antibiotic treatment (i.e. high negative predictive value), but there is still a place for the experienced and skilled clinician to decide when to start or escalate antibiotic treatment (at procalcitonin concentrations $>0.1 \mathrm{ng} / \mathrm{mL}$ ) based on clinical grounds in accordance with the setting and context of the patient.

Reports that antibiotic therapy of $\mathrm{COPD}^{53}$ and $\mathrm{CAP}^{54}$ can be shortened are of great interest, even though the question of an optimal duration of antibiotic therapy remains to be settled. A recent meta-analysis documented that the prescribing of any antibiotic in primary care increases the risk that bacteria develop antibiotic resistance in the individual (odds ratio 2.4 ), the impact lasting for more than one year. ${ }^{55}$ It follows that, in order to combat the increasing incidence of antibiotic-resistant bacteria, we must seek to minimise the number of antibiotic courses initiated without jeopardising the safety of our patients.

However, before the widespread introduction of procalcitonin in primary care can be recommended, we need to have evidence from pragmatic trials, cost-effectiveness studies, verified cut-off values, and a 'head-to-head' trial with CRP. The introduction of a validated, cost-effective, present-best biomarker to predict benefit from antibiotic therapy may mark an important milestone in evidence-based medicine in primary care in the foreseeable future.

\section{Handling editor \\ Mike Thomas}

\section{Acknowledgements}

The authors wish to thank the Procalcitonin and Antibiotics in Respiratory Infections (PARI) advisory board (Niels de Fine Olivarius, Lars Bjerrum, Volkert Siersma and Frans Boch Waldorff) for comments and fruitful discussions.

\section{Conflicts of interest}

Rune Aabenhus: None declared

Jens-Ulrik Stæhr Jensen: Received an unrestricted grant in 2008 from Brahms Diagnostica, Heningsdorf, Germany, and has participated in symposia sponsored by Brahms Diagnostica, Heningsdorf, Germany, the last being held more than one year ago.

\section{Contributorship}

Both authors contributed to the idea and analysed data. Rune Aabenhus wrote and edited the manuscript. Jens-Ulrik Stæhr Jensen edited the manuscript. 


\section{Funding}

Rune Aabenhus. Grant from Praktiserende Lægers Udviklingsfond (The general practitioners' fund for development). Jens-Ulrik Stæhr Jensen: No funding. The study has been done during out-of-work hours.

\section{References}

1. Boucher HW, Talbot GH, Bradley JS, et al. Bad bugs, no drugs: no ESKAPE! An update from the Infectious Diseases Society of America. Clin Infect Dis 2009;48(1):1-12. http://dx.doi.org/10.1086/595011

2. Goossens $H$, Ferech M, Vander SR, Elseviers M. Outpatient antibiotic use in Europe and association with resistance: a cross-national database study. Lancet 2005;365(9459):579-87.

3. Sande-Bruinsma N, Grundmann H, Verloo D, et al. Antimicrobial drug use and resistance in Europe. Emerg Infect Dis 2008;14(11):1722-30. http://dx.doi.org/10.3201/eid1411.070467

4. Metlay JP, Kapoor WN, Fine MJ. Does this patient have community-acquired pneumonia? Diagnosing pneumonia by history and physical examination. JAMA 1997;278(17):1440-5. http://dx.doi.org/10.1001/jama.278.17.1440

5. Hoare Z, Lim WS. Pneumonia: update on diagnosis and management. BMJ 2006;332(7549):1077-9. http://dx.doi.org/10.1136/bmj.332.7549.1077

6. Wipf JE, Lipsky BA, Hirschmann JV, et al. Diagnosing pneumonia by physical examination: relevant or relic? Arch Intern Med 1999;159(10):1082-7. http://dx.doi.org/10.1001/archinte.159.10.1082

7. Matthys J, De MM, van Driel ML, De SA. Differences among international pharyngitis guidelines: not just academic. Ann Fam Med 2007;5(5):436-43. http://dx.doi.org/10.1370/afm.741

8. Arnold SR, Straus SE. Interventions to improve antibiotic prescribing practices in ambulatory care. Cochrane Database Syst Rev 2005;(4):CD003539.

9. Fakih MG, Berschback J, Juzych NS, Massanari M. Compliance of resident and staff physicians with IDSA guidelines for the diagnosis and treatment of streptococcal pharyngitis. Infect Dis Clin Pract 2006;14:84-8. http://dx.doi.org/10.1097/01.idc.0000198462.55744.f8

10. Little P. Penicillin for acute sore throat in children: randomised, double blind trial. Commentary: More valid criteria may be needed. BMJ 2003;327(7427):1327-8. http://dx.doi.org/10.1136/bmj.327.7427.1327

11. Gonzales R, Malone DC, Maselli JH, Sande MA. Excessive antibiotic use for acute respiratory infections in the United States. Clin Infect Dis 2001;33(6):75762. http://dx.doi.org/10.1086/322627

12. Shehab N, Patel PR, Srinivasan A, Budnitz DS. Emergency department visits for antibiotic-associated adverse events. Clin Infect Dis 2008;47(6):735-43. http://dx.doi.org/10.1086/591126

13. Butler CC, Simpson S, Wood F. General practitioners' perceptions of introducing near-patient testing for common infections into routine primary care: a qualitative study. Scand J Prim Health Care 2008;26(1):17-21. http://dx.doi.org/10.1080/02813430701726285

14. Becker KL, Snider R, Nylen ES. Procalcitonin assay in systemic inflammation, infection, and sepsis: clinical utility and limitations. Crit Care Med 2008;36(3):941-52. http://dx.doi.org/10.1097/CCM.0B013E318165BABB

15. Schuetz P, Christ-Crain M, Thomann R, et al. Effect of procalcitonin-based guidelines vs standard guidelines on antibiotic use in lower respiratory tract infections: the ProHOSP randomized controlled trial. JAMA 2009;302(10):1059-66. http://dx.doi.org/10.1001/jama.2009.1297

16. Briel M, Schuetz P, Mueller B, et al. Procalcitonin-guided antibiotic use vs a standard approach for acute respiratory tract infections in primary care. Arch Intern Med 2008;168(18):2000-07. http://dx.doi.org/10.1001/archinte.168.18.2000

17. Christ-Crain M, Schuetz $P$, Muller B. Biomarkers in the management of pneumonia. Expert Rev Respir Med 2008;2(5):565-72. http://dx.doi.org/10.1586/17476348.2.5.565

18. Becker KL, Nylen ES, White JC, Muller B, Snider RH Jr. Clinical review 167: Procalcitonin and the calcitonin gene family of peptides in inflammation, infection, and sepsis: a journey from calcitonin back to its precursors. J Clin Endocrinol Metab 2004;89(4):1512-25. http://dx.doi.org/10.1210/jc.2002-021444

19. Snider RH, Jr., Nylen ES, Becker KL. Procalcitonin and its component peptides in systemic inflammation: immunochemical characterization. I Investig Med 1997;45(9):552-60.

20. Linscheid P, Seboek D, Schaer DJ, Zulewski H, Keller U, Muller B. Expression and secretion of procalcitonin and calcitonin gene-related peptide by adherent monocytes and by macrophage-activated adipocytes. Crit Care Med 2004;32(8):1715-21. http://dx.doi.org/10.1097/01.CCM.0000134404.63292.71

21. Linscheid P, Seboek D, Nylen ES, et al. In vitro and in vivo calcitonin I gene expression in parenchymal cells: a novel product of human adipose tissue. Endocrinology 2003;144(12):5578-84. http://dx.doi.org/10.1210/en.2003-0854

22. Christ-Crain M, Muller B. Procalcitonin in bacterial infections-hype, hope, more or less? Swiss Med Wkly 2005;135(31-32):451-60.

23. Dandona $\mathrm{P}$, Nix $\mathrm{D}$, Wilson $M F$, et al. Procalcitonin increase after endotoxin injection in normal subjects. J Clin Endocrinol Metab 1994;79(6):1605-08. http://dx.doi.org/10.1210/jc.79.6.1605

24. Meisner M, Schmidt J, Huttner $H$, Tschaikowsky K. The natural elimination rate of procalcitonin in patients with normal and impaired renal function. Intensive Care Med 2000;26(Suppl 2):S212-16.

25. Gaini S, Koldkjaer OG, Moller HJ, Pedersen C, Pedersen SS. A comparison of high-mobility group-box 1 protein, lipopolysaccharide-binding protein and procalcitonin in severe community-acquired infections and bacteraemia: a prospective study. Crit Care 2007;11(4):R76. http://dx.doi.org/10.1186/cc5967

26. Daubin C, Parienti JJ, Fradin S, et al. Procalcitonin levels and bacterial aetiology among COPD patients admitted to the ICU with severe pneumonia: a prospective cohort study. BMC Infect Dis 2009;9:157. http://dx.doi.org/10.1186/1471-2334-9-157

27. Moulin F, Raymond J, Lorrot $\mathrm{M}$, et al. Procalcitonin in children admitted to hospital with community acquired pneumonia. Arch Dis Child 2001;84(4):332-6. http://dx.doi.org/10.1136/adc.84.4.332

28. Holm A, Pedersen SS, Nexoe J, et al. Procalcitonin versus C-reactive protein for predicting pneumonia in adults with lower respiratory tract infection in primary care. Br J Gen Pract 2007; 57(540):555-60.

29. Ingram PR, Inglis T, Moxon D, Speers D. Procalcitonin and C-reactive protein in severe 2009 H1N1 influenza infection. Intensive Care Med 2010;36(3):528-32. http://dx.doi.org/10.1007/s00134-009-1746-3

30. Jensen JU, Heslet L, Jensen TH, Espersen K, Steffensen P, Tvede M. Procalcitonin increase in early identification of critically ill patients at high risk of mortality. Crit Care Med 2006;34(10):2596-602. http://dx.doi.org/10.1097/ 01.CCM.0000239116.01855.61

31. Nylen ES, Whang KT, Snider RH, Jr., Steinwald PM, White JC, Becker KL. Mortality is increased by procalcitonin and decreased by an antiserum reactive to procalcitonin in experimental sepsis. Crit Care Med 1998;26(6):1001-06. http://dx.doi.org/10.1097/00003246-199806000-00015

32. Schuetz P, Christ-Crain M, Muller B. Procalcitonin and other biomarkers to improve assessment and antibiotic stewardship in infections-hope for hype? Swiss Med Wkly 2009;139(23-24):318-26.

33. Kruger S, Ewig S, Papassotiriou J, et al. Inflammatory parameters predict etiologic patterns but do not allow for individual prediction of etiology in patients with CAP: results from the German competence network CAPNETZ. Respir Res 2009;10:65. http://dx.doi.org/10.1186/1465-9921-10-65

34. Korczowski B, Malek U, Kowalczyk JR, Rybak A, Zinkiewicz A, Chmielewska A. [Two diagnostic assays for serum procalcitonin measurement in clinical practice]. Przegl Lek 2003;60(5):345-8.

35. Christ-Crain M, Opal SM. Clinical review: the role of biomarkers in the diagnosis and management of community-acquired pneumonia. Crit Care 2010;14(1):203. http://dx.doi.org/10.1186/cc8155

36. Steinbach G, Rau B, Debard AL, et al. Multicenter evaluation of a new immunoassay for procalcitonin measurement on the Kryptor System. Clin Chem 
Lab Med 2004;42(4):440-9. http://dx.doi.org/10.1515/CCLM.2004.077

37. Schuetz P, Albrich W, Christ-Crain M, Chastre J, Mueller B. Procalcitonin for guidance of antibiotic therapy. Expert Rev Anti Infect Ther 2010;8(5):575-87. http://dx.doi.org/10.1586/eri.10.25

38. Burkhardt O, Ewig S, Haagen $U$, et al. Procalcitonin guidance and reduction of antibiotic use in acute respiratory tract infection. Eur Respir J 2010;36(3):601-07.

39. Woodhead M, Blasi F, Ewig S, et al. Guidelines for the management of adult lower respiratory tract infections. Eur Respir J 2005;26(6):1138-80. http://dx.doi.org/10.1183/09031936.05.00055705

40. Melbye H, Dale K. Interobserver variability in the radiographic diagnosis of adult outpatient pneumonia. Acta Radiol 1992;33(1):79-81.

41. Wilkins TR, Wilkins RL. Clinical and radiographic evidence of pneumonia. Radiol Technol 2005;77(2):106-10.

42. Sethi S, Murphy TF. Infection in the pathogenesis and course of chronic obstructive pulmonary disease. N Engl J Med 2008;359(22):2355-65. http://dx.doi.org/10.1056/NEJMra0800353

43. Dinant GJ, Buntinx FF, Butler CC. The necessary shift from diagnostic to prognostic research. BMC Fam Pract 2007;8:53. http://dx.doi.org/10.1186/1471-2296-8-53

44. Korppi M, Remes S, Heiskanen-Kosma T. Serum procalcitonin concentrations in bacterial pneumonia in children: a negative result in primary healthcare settings. Pediatr Pulmonol 2003;35(1):56-61. http://dx.doi.org/10.1002/ppul.10201

45. Deis JN, Creech CB, Estrada CM, Abramo TJ. Procalcitonin as a marker of severe bacterial infection in children in the emergency department. Pediatr Emerg Care 2010;26(1):51-60. http://dx.doi.org/10.1097/PEC.0b013e3181c399df

46. Hopstaken RM, Coenen S, Butler CC. Treating patients not diagnoses: challenging assumptions underlying the investigation and management of LRTI in general practice. J Antimicrob Chemother 2005;56(5):941-3. http://dx.doi.org/10.1093/jac/dki330

47. Stanton N, Francis NA, Butler CC. Reducing uncertainty in managing respiratory tract infections in primary care. Br J Gen Pract 2010;60(581):e46675. http://dx.doi.org/10.3399/bjgp10X544104

48. Cals JW, Butler CC, Hopstaken RM, Hood K, Dinant GJ. Effect of point of care testing for $C$ reactive protein and training in communication skills on antibiotic use in lower respiratory tract infections: cluster randomised trial. BMJ 2009;338:b1374. http://dx.doi.org/10.1136/bmj.b1374

49. Cals JW, Schot MJ, de Jong SA, Dinant GJ, Hopstaken RM. Point-of-care Creactive protein testing and antibiotic prescribing for respiratory tract infections: a randomized controlled trial. Ann Fam Med 2010;8(2):124-33. http://dx.doi.org/10.1370/afm.1090

50. Cals JW, Metlay JP. Procalcitonin-based guidelines and lower respiratory tract infections. JAMA 2010;303(5):418-20. http://dx.doi.org/10.1001/jama.2010.52

51. Huang DT, Weissfeld LA, Kellum JA, et al. Risk prediction with procalcitonin and clinical rules in community-acquired pneumonia. Ann Emerg Med 2008;52(1):48-58. http://dx.doi.org/10.1016/j.annemergmed.2008.01.003

52. Kruger S, Ewig S, Marre R, et al. Procalcitonin predicts patients at low risk of death from community-acquired pneumonia across all CRB-65 classes. Eur Respir J 2008;31(2):349-55. http://dx.doi.org/10.1183/09031936.00054507

53. El MR, Roede BM, Speelman P, Bresser P, Prins JM, Bossuyt PM. Short-course antibiotic treatment in acute exacerbations of chronic bronchitis and COPD: a meta-analysis of double-blind studies. Thorax 2008;63(5):415-22. http://dx.doi.org/10.1136/thx.2007.090613

54. Dimopoulos G, Matthaiou DK, Karageorgopoulos DE, Grammatikos AP, Athanassa Z, Falagas ME. Short-versus long-course antibacterial therapy for community-acquired pneumonia: a meta-analysis. Drugs 2008;68(13):184154. http://dx.doi.org/10.2165/00003495-200868130-00004

55. Costelloe C, Metcalfe C, Lovering A, Mant D, Hay AD. Effect of antibiotic prescribing in primary care on antimicrobial resistance in individual patients: systematic review and meta-analysis. BMJ 2010;340:c2096. http://dx.doi.org/10.1136/bmj.c2096

\section{COMMENTARY}

\section{Inflammatory markers are helpful when treating LRTI in primary care}

\section{Hasse Melbye ${ }^{a}$, Nick A Francis ${ }^{b},{ }^{*}$ Christopher C Butler ${ }^{c}$}

a Professor of general practice, Department of Community Medicine, Faculty of Health Science, University of Tromsø, Norway

b Senior Clinical Research Fellow, Department of Primary Care and Public Health, School of Medicine, Cardiff University, Cardiff, UK c Professor of primary care medicine, Department of Primary Care and Public Health, School of Medicine, Cardiff University, Cardiff, UK

Antibiotic resistance is a growing problem, and unnecessary antibiotic use exposes people to the risk of adverse reactions, wastes money, and medicalises self-limiting conditions. Better targeting of antibiotics is therefore essential - especially in primary care, where most antibiotics are prescribed.

Inflammatory markers like C-reactive protein (CRP) and procalcitonin (PCT) do not adequately differentiate between bacterial and viral infection. ${ }^{1}$ CRP is a better predictor of pneumonia than any symptom or sign. ${ }^{2}$ The diagnostic value of PCT has been less studied in primary care, probably because a Near Patient Test (NPT) version is not yet available. However, it seems to be a less sensitive marker of pneumonia than CRP. ${ }^{3,4}$ Nevertheless, as Aabenhus and Jensen point out in this comprehensive review, ${ }^{5}$ both the PCT and CRP tests have proved useful in guiding clinicians' prescribing decisions so as to achieve a reduction in unnecessary antibiotic use. ${ }^{5,6} \mathrm{~A}$ CRP NPT result can be obtained in under five minutes, and results are strongly weighted by GPs in Scandinavia when deciding on antibacterial treatment in patients with acute cough.?

Inflammatory markers are more useful as a guide when deciding on antibacterial treatment in primary care rather than in secondary care; in the former an aetiological diagnosis may be

\footnotetext{
* Corresponding author: Professor Christopher Butler, Department of Primary Care and Public Health, School of Medicine, Cardiff University, 3rd Floor, Neuadd Meirionnydd, Heath Park, Cardiff, CF14 4XN. E-mail: ButlerCC@cf.ac.uk
} 